\title{
Subclinical Infection of the Silicone Breast Implant Surface as a Possible Cause of Capsular Contracture: A Follow-Up
}

\author{
Marek Dobke $^{1} \cdot$ Adam Hauch $^{1} \cdot$ Jiwon Crowley $^{1}$
}

Published online: 5 August 2020

(C) Springer Science+Business Media, LLC, part of Springer Nature and International Society of Aesthetic Plastic Surgery 2020

Research on seemingly dormant microbes and biofilm at the surface of mammary implants was inspired by Dr. Burkhardt's original concepts on the role of subclinical infection and fibrous capsular contracture around breast implants [1]. Early on, the relevance of such a question as whether there is any local, cellular, genotypic or phenotypic predisposition necessary to "allow" contracture to develop was reaffirmed first by us and later on by the observations of others who noted that when implants were placed in a "sterile" tissue environment, capsular contracture was virtually unheard of $[2,3]$. Questions began to focus on the clinical significance of the presence of bacteria and their by-products. These questions led to the investigation of whether bacteria and microbial by-products not only alter the healing and biological behavior of tissue in the immediate vicinity of the implant but also potentially exert systemic effects as well [4].

Although the hypothesis postulating whether microbes play a key role in the development of capsular contracture required (and still requires to this day) further investigation, practical suggestions emerged on how to prevent and/ or treat presumed subclinical infections. Goals to eliminate bacteria from the surface of implants led the development of "therapeutic protocols" and, perhaps more importantly, precipitated research regarding the development of bacteria/biofilm-repellent surfaces $[5,6]$. These attempts to prevent and to "treat" the presence of bacteria on the surface of implants led to inconsistent results [7]. Despite these inconsistencies, recognition of pathophysiological

Marek Dobke

mdobke@health.ucsd.edu

1 Division of Plastic Surgery, Department of Surgery, University of California San Diego, 200 West Arbor Drive, San Diego, CA 92103-8890, USA details of the implant surface-breast tissue microenvironment and their interaction broadened plastic surgeons' perspectives on the issues of biofilms. Additionally, this helped guide plastic surgeons toward the understanding of the inconsistency and unpredictability of the effectiveness of local antimicrobials thus providing the impetus for some technical modifications of implant insertion (e.g., the Keller Funnel) [5, 8].

Skin and breast tissue (as specialized skin appendage) contain a robust environment of microbiota, and even with submuscular positioning of implants, some contact with breast tissue is unavoidable $[6,7,9]$. Interestingly, the isolates obtained from implants by the disruption of biofilm consist mostly of Staphylococcus epidermidis, which differs from the typical tissue microbiota isolated from breast tissue $[1,10]$. This capability, phenotypic "effectiveness" and biologically rapid (in seconds) protective action make these bacteria themselves, which are quickly encased in biofilm, inaccessible to antibacterial agents. On the other hand, microbial species, less efficient in the formation of biofilm, may be successfully eradicated by antimicrobials $[1,7,11-13]$. In addition, the virulence of many of Staphylococcal biofilms, their resistance to the host's endogenous defenses and antibiotics, is related to their ability to form thicker and stronger biofilms with biofilm "protective" mechanisms in place compared to other species [13]. Currently, the importance of the development of a bacteria/biofilm-repellent medical device surfaces is recognized by many clinical specialties and goes well beyond the focus of mammary implants [13-15].

Both our study and the studies of others have evolved to focus on the further characterization of biofilm, its components and the potential significance it has on the development of systemic effects in some breast implant recipients. Polymerase chain reaction assay has allowed for 
the detection of heat shock proteins in tissue materials interacting with biofilms [4, 16-20]. In the context of the discussion of "Breast Implant Illness" (BII) and breast implant-associated anaplastic large cell lymphoma (BIAALCL), it is worthy to mention that one of these proteins (heat shock protein-90) mediates self-nucleic acid recognition in systemic autoimmune diseases and has also become a known factor for promoting the development of anaplastic large cell lymphoma [16-21]. Therefore, although studies branching from the issues of "subclinical infection and capsular contracture" have generated more questions than answers, there should be no doubt that the interface between mammary implants and the host tissues may be the site of chronic inflammation and, in some molecular/genetic circumstances, may stimulate the immune system leading to secondary disorders and systemic illnesses [19]. Investigation of the role of toll-like receptors in peri-implant implant tissue is a very logical step forward in an attempt to establish the pathophysiology and molecular evidence behind BII. This study and others aimed to dissect molecular mechanisms behind the condition would perhaps allow us to determine whether indeed there are patients who should not be recipients of breast implants [20-23].

Considering the fact that immune alterations and chronic inflammatory profiles may have a similar pathophysiology regardless of whether reactions are considered "local", and limited to the surrounding breast environment, or systemic; the hypothesis that capsular contracture and breast implant illness share the same initial pathogenesis and are on a continuum of the same chronic inflammatory spectrum is reasonable [22-26]. The combination of the presence of toxic or immunizing-capable detachment molecules from Staphylococcus epidermidis biofilms as well as some silicone gel adjuvant potency may lead to different reactions ranging from local-in some circumstances unilateralfibrosis (capsular contracture) through systemic ones (fibromyalgia, BII) [10, 22-27]. Therefore, it should not be surprising that the outcomes from implant explanation or periprosthetic capsulectomy are inconsistent and often not permanent-once the systemic inflammatory cascade is activated, it tends to have its own dynamic course and the elimination of antigens and the site of local inflammation may not result in the resolution of the multitude of symptoms and problems that may be present $[4,17,18,22-26]$.

Reflecting back on the initial studies on "subclinical infection of mammary implants" and re-reading the last paragraph of the article from 1992, we are reaffirmed that although some issues and questions were raised rather intuitively, the research and concepts that originated at that time were "on the right track". Additionally, in the particular context of BII, the recognition that the physical characteristics of the implant surface may modulate microbial deposits and the nature of biofilms suggests that further investigations are warranted [28]. Large databases (e.g., the National Breast Implant Registry) should facilitate the accumulation of relevant information and the effective transition from data collection and analysis to scientific "synthesis" and clinical applications. We hope that further research in this field of investigation will bring us even closer to the concept of "precision" medicine and surgery, such that it may be possible to truly personalize breast implant surgery and increase the margin of implant safety.

Funding The authors have no disclosures.

\section{References}

1. Burkhardt B (1985) Fibrous capsular contracture around breast implants: the role of subclinical infection. Infect Surg 4:469

2. Johnson N, Cassar S, Bhatt S, Dogra VS (2009) Fibrous capsular contracture of a testicular implant. J Ultrasound Med 28:263-265

3. Parsons CL, Stein PC, Dobke MK, Virden CP, Frank DH (1993) Diagnosis and treatment of subclinically infected prostheses. Surg Gyn Obstet 177:504-506

4. Dobke MK, Svahn JK, Vastine VL, Landon BN, Stein PC, Parsons CL (1995) Characterization of microbial presence at the surface of mammary implants. Ann Plast Surg 34:563-569

5. Adams WP Jr (2009) Capsular contracture: what is it? What causes it? How can it be prevented and managed? Clin Plast Surg 36:119-126

6. Dobke MK (1997) The treatment of "infected" mammary implants: rationale and suggested guidelines. Aesth Surg J 17:54-59

7. Drinane JJ, Bergman RS, Folkers BL, Kortes MJ (2013) Revising triple antibiotic irrigation of breast implant pockets: a placebocontrolled single practice cohort study. Plast Reconstr Surg Glob Open 1:e55

8. Suseela BB, Thiruvoth FM, Penumadu P, Chittoria RK, Mohapatra DP, Kumar SH (2016) An alternative method of breast implant insertion. Aesth Surg J 36:287-288

9. Hieken TJ, Chen J, Hoskin TL, Wather-Antonio M, Johnson S, Ramaker S, Xiao J, Radisky DC, Knutson KL, Kalari KR, Yao JZ, Baddour LM, Chia N, Degnim AC (2016) The microbiome of aseptically collected human breast tissue in benign and malignant disease. Sci Rep 6:30751

10. Chessa D, Ganau G, Spija L, Bulla A, Mazzarello V, Campus GV, Rubino S (2016) Staphylococcus aureus and Staphylococcus epidermidis virulence strains as causative agents of persistent infections in implants. PLoS ONE 11:e0146668

11. O'Gara JP, Humphreys H (2001) Staphylococcus epidermidis biofilms: importance and implications. J Med Microbiol 50:582-587

12. Vandecasteele SJ, Peetermans WE, Merckx R, Van Eldere J (2003) Expression of biofilm-associated genes in Staphylococcus epidermidis during in vitro and in vivo foreign bodies. J Infect Dis $188: 730-737$

13. Khatoon Z, McTiernan CD, Suuronen EJ, Mah TF, Alacron EI (2018) Bacterial biofilm formation on implantable devices and approaches to its treatment and prevention. Heliyon 4:e1067

14. The Institute of Photonic Sciences (ICFO) (2019) Light and nanotechnology combined to prevent biofilms on medical 
implants. Med Des Briefs. https://www.medicaldesignbriefs.com/ component/content/article/mdb/features/global-innovations/ 34804

15. Magennis EP, Hook AL, Williams P, Alexander MR (2016) Making silicone rubber highly resistant to bacterial attachment using thiol-ene grafting. ACS Appl Mater Interfaces 8:30780-30787

16. Dobke MK, Grzybowski J, Stein P, Landon BN, Dobak J, Parsons CL (1994) Fibroblast behavior in vitro is unaltered by products of Staphylococci cultured from silicone implants. Ann Plast Surg 32:118-125

17. Landon BN, Dobke MK, Grzybowski J, Virden CP, Dobak J, Steinsapir ES (1993) Enhanced activity of lysosomal betagalactosidase after silicone implantation: an experimental study in rats. J Lab Clin Med 121:742-750

18. Magnusson MR, Cooter RD, Rakhorst H, McGuire PA, Adams WP Jr, Deva AK (2019) Breast implant illness: a way forward. Plast Reconstr Surg 143:74S-81S

19. Pearson JD, Mohammed Z, Bacani JT, Lai R, Ingham RJ (2012) The heat shock protein-90 co-chaperone Cyclophilin 40, promotes ALK-positive, anaplastic large cell lymphoma viability and its expression is regulated by the NPM-ALK oncoprotein. BMC Cancer 12:229

20. Saito K, Kukita K, Kutomi G, Okuya K, Asanuma H, Tabeya T, Nashiro Y, Yamamoto M, Takahashi H, Torigoe T, Nakai A, Shinomura Y, Hirata K, Sat N, Tamura Y (2015) Heat shock protein 90 associates with Toll-like receptors $7 / 9$ and mediates self-nucleic recognition in SLE. Eur J Immunol 45:2028-2041

21. Valbuena JR, Rassidakis GZ, Lin P, Atwell C, Georgakis GV, Younes JD, Medeiros LJ (2005) Expression of heat-shock protein-90 in non-Hodgkin lymphoma. Mod Pathol 18:1343-1349
22. Bizjak M, Selmi C, Praprotnik S, Bruck O, Perricone C, Ehrenfeld M, Shoenfeld Y (2015) Silicone implants and lymphoma: the role of inflammation. J Autoimmun 65:64-73

23. Bachour Y, Ritt MJPF, Heijmans R, Niessen FB, Verweij SP (2019) Toll-Like receptors (TLRs) expression in contracted capsules compared to uncontracted capsules. Aesthet Plast Surg 43:910-917

24. Araco A, Caruso R, Araco F, Overton J, Gravante G (2009) Capsular contractures: a systematic review. Plast Reconstr Surg 124:1808-1819

25. Steiert AE, Boyce M, Sorg H (2013) Capsular contracture by silicone breast implants: possible causes, biocompatibility, and prophylactic strategies. Med Dev (Auckl) 6:211-218

26. Svahn JK, Vastine VL, Landon BN, Dobke MK (1996) Outcome of mammary prostheses explantation: a patient perspective. Ann Plast Surg 36:594-600

27. Wang R, Khan BA, Cheung GY, Bach TH, Jameson-Lee M, Kong KF, Queck SY, Otto M (2011) Staphylococcus epidermidis surfactant peptides promote biofilm maturation and dissemination of biofilm-associated infection in mice. J Clin Invest 12:238-248

28. Munhoz AM, Clemens MW, Nahabedian MY (2019) Breast implant surfaces and their impact on current practices: where we are now and where we are going? Plast Reconstr Surg Glob Open 7:e2466

Publisher's Note Springer Nature remains neutral with regard to jurisdictional claims in published maps and institutional affiliations. 